\title{
The Perceptions between Teachers' in Public and Private Schools related to the (LFH) Learn from Home Policy
}

\begin{tabular}{c} 
Sari Wahyuni ${ }^{1}$, Ariyanti $^{\mathbf{2}}$ \\
Universitas Widya Gama Mahakam, Indonesia ${ }^{1,2}$ \\
Email Correspondence: sariyuni681@gmail.com \\
\hline
\end{tabular}

\begin{abstract}
Knowledge of the various kinds of teacher perceptions between 2 different schools about LFH policies will increase our knowledge of each teacher's strengths and weaknesses in learning activities using LFH policies during the pandemic. This research was conducted in private schools SD Darul Falah 2 Samarinda and public schools SDN 019 Muara Badak, namely four teachers and two principals. It collected data in this study using interview techniques to determine the strengths and weaknesses of LFH policies from teacher perceptions of LFH policies and questionnaire techniques to support interviews with teachers. Furthermore, The results showed that $24 \%$ of private school teachers' perceptions of the LFH policy were included in the "Disagree" category. Similar to private schools, the results showed that public school teachers' perceptions of LFH policies, namely $23.5 \%$, were also included in the "Disagree" category. From these two results, it can be concluded that the average teacher disagrees with the LFH policy because it is considered to have many deficiencies that can impact current education development. The data subject was challenged to face in the learning process because the situation made students and teachers need a high focus level to understand what was conveyed by the teacher in daring or online learning.
\end{abstract}

Keywords: Teachers' Perceptions; Public and Private Schools; Educational Policy; Learn From Home (LFH) Policy

\begin{tabular}{|c|c|c|}
\hline DOI & $:$ & https://doi.org/10.24903/bej.v2i2.631 \\
\hline Received & : & February 2020 \\
\hline Accepted & : & June 2020 \\
\hline Published & : & August 2020 \\
\hline $\begin{array}{l}\text { Copyright and } \\
\text { License }\end{array}$ & $:$ & $\begin{array}{l}\text { Authors retain copyright and grant the journal right of first publication with the } \\
\text { work simultaneously licensed under a Creative Commons Attribution 4.0 } \\
\text { International License that allows others to share the work with an acknowledgement of } \\
\text { the work's authorship and initial publication in this journal. } \\
\text { cC) }\end{array}$ \\
\hline
\end{tabular}




\section{INTRODUCTION}

Children can be independent in carrying out their life tasks without expecting help from others. Furthermore [1] says that education provides us with provisions that did not exist in childhood, but we need them when we grow up. In general, education is essential to do as early as possible to help develop themselves in various aspects, children's character will be formed during the golden age, so it is better to provide children's education from an early age.

In this case, the researcher conducts research first to find and confirm the problem to be studied; within one month, the researcher conducts an interview, where a pandemic and a policy is issued that requires teaching and learning activities to be carried out from home. Researchers conducted short, informal interviews with one teacher in a public school and one student and student guardians in a private school. After that, the researcher analyzed the differences in the interviews with different teachers, where the researcher found the research subjects of different teachers where they taught.

At this time, Indonesia is facing a virus that has caused student learning and teaches a teacher to change, thereby making students and teachers teach and learn at home online or online. The connection is that during this pandemic period it has a more effect on making students and teachers have to adapt again to the concept of learning online or online by ole because it is to find out how different perceptions of teachers who teach in public schools and private schools on learning from home policies. In addition to looking for differences in the perceptions of private and general teachers, this study has a purpose where in addition to explaining or describing how the teacher's perceptions are, this study also wants to provide detailed knowledge about how the COVID-19 virus causes different teachers' perceptions of teaching conducted at home online or daring. Besides, this study aims to provide references to the same topic, particularly teacher perceptions in the "Learning From Home" policy.

\section{METHODOLOGY}

This research uses a qualitative approach with a case study design supported by a quantitative approach [2]. This design is the right design to see what teachers' perceptions of Learning from Home (LFH) policies are, how teachers' perceptions about the Ministry of Education and Culture's policies to realize the right of education for future generations. As stated by [3], a case study is a qualitative approach used to understand an issue or problem in a case. Furthermore, the researcher conducted a study in private schools and public schools, with four teachers and two principals. 
As Poulsen (2019) suggests, the interviewer needs to explore further a topic based on participants' answers. The order of questions and discussion does not have to be the same as in the guide. It all depends on the course interview because keeping in mind that information is obtained directly from the first source. Moreover, the researcher did the interview; the researcher also gave a questionnaire to the subjects to increase the data more credible with the Agusta (2014) questionnaire. The researcher formulated several steps in this instrument as follows:

1. The researcher distributed questionnaires to each subject.

2. The researcher started the interview using open-ended questions.

3. The researcher interviewed one subject

4. The researcher fulfilled the subject's answers in the form of interviews

5. The researcher took an audio recording during the interview session with the subject.

Moreover, after the researcher got the result, the researcher did data analysis to make the result clear and valid with [4]'s data analysis quote (2013).

\section{FINDINGS}

The study results consisted of two parts, namely data from a questionnaire given to teachers from public and private schools and data from an interview conducted by four teachers and two principals from public and private schools. From the results of the interview, the researchers obtained information on various actions that the school had taken in following the LFH policy as follows:

\subsection{Data from Interview}

The responses of private and public school principals have something in common regarding LFH policies, namely that schools have implemented LFH policies after the issuance of educational regulations during the pandemic by the Minister of Education and Culture, all teachers and students continue to carry out learning activities in their respective homes following LFH policies. Therefore, the teacher did some activity to increase and make a solution in the learning process, consider the Pandemic COVID-19 situation.

Teachers create groups on WhatsApp containing teachers and parents of students, for the sake of smooth teaching and learning activities for teachers and parents of students to coordinate with each other for student learning development, here parents substitute teachers at school. No different from what is done in private schools, teachers in public schools teach using the WhatsApp application by sending material and explanatory videos about the material 
to parents to convey to their children, but what is different from private schools is that teachers do not have books lesson.

\subsection{Data from Questionnaire}

The researcher gave the questionnaire to teachers in two different schools determined by the researcher; 1). The data obtained shows that on average private school teachers do not support teaching and learning activities during the LFH policy, with an average score of 1.2 with 24\%, including the "Disagree" category. However, this result impacts students and teachers because one of the challenges of the problem faced by students and the teacher is the lack of facilitating, besides the result from public school. Furthermore, the teacher's research on two public school teachers showed an average score of 1.17 with a percentage of $23.5 \%$, including the category "Disagree." The data obtained shows that on average private school teachers do not support teaching and learning activities during the LFH policy. Likewise with the results of a questionnaire from private school teachers. The lack of adequate facilities and the many complaints from parents adds to the teacher's own thinking

\section{DISCUSSION}

From the interview results, the researcher found that private and public school teachers had difficulty communicating with parents to develop student education. Many parents do not have facilities that support learning activities with LFH. Meanwhile, parents who do not easily understand the learning material even though the teacher has explained. This fact means that the researcher's findings have something in common with the theory put forward by [5] that in order to improve the quality of LFH sustainability, several essential things must be pursued, among others. First, educational institutions must begin to improve facilities and infrastructure to support online learning such as infrastructure, Learning Management systems, and adequate repositories.

The questionnaire results found that teachers' perceptions of LFH policies were that teachers had ease and difficulty carrying out teaching activities with LFH. Teaching with LFH made teachers more creative and innovative and became proficient in using technology LFH policies required online learning.

\section{CONCLUSION}

In addition to providing questionnaires, analysts also conduct interviews to get deeper reasons besides articulating the questionnaire. From this emerges, there are similarities in recognition, and there are two differences in the sharpness that each educator provides. Private 
school instructors communicate challenges when educating with LFH due to the need for offices that support teaching and learning exercises by instructors, guardians, and students. However, the learning books they make are very helpful in understanding the material by students. Some instructors feel less demanding to instruct using innovation because it makes more sense when making educational materials for learning in the middle of LFH. Meanwhile, along with the school instructor's opening, leaving the unsupported office, instructors also received few complaints from parents regarding their failure to provide learning tools for children and an understanding of the material provided by the instructors. It is different from private schools

\section{REFERENCES}

[1] K. R. Lorig and H. R. Holman, "Self-Management Education: History, definition, outcomes, and mechanisms," Ann. Behav. Med., p. 23, 2003.

[2] J. W. Creswell, Educational Research. Boston: Pearson, 2012.

[3] J. W. Creswell, Research Design: Qualitative, Quantitative and Mixed Method Aproaches. London: SAGE Publication, Inc, 2007.

[4] J. W. Creswell, Qualitative Inquiry and Research Design Choosing among Five Approaches, 3rd ed. London: SAGE Publication Ltd, 2013.

[5] Hikmat, E. Hermawan, Aldim, and Irwandi, "Efektivitas Pembalajaran Daring Selama Masa Pandemi Covid-19 : Sebuah Survey Online,” Digit. Libr. UIN SUnan Gung Djati, Bandung, vol. 9, no. 15, 2020. 